Volume 1, Nomor 2, September 2019, pp 26-47. Copyright (C 2019 JAFTA, Program Studi Magister Akuntansi, Fakultas Ekonomi, Universitas Kristen Maranatha. ISSN: 2654-4636| E-ISSN: 2656-758X https://journal.maranatha.edu/index.php/jafta

\title{
Pengaruh Pengetahuan Peraturan Perpajakan Dan Kualitas Pelayanan Terhadap Kepatuhan Wajib Pajak Pada Kantor Pelayanan Pajak Pratama Bandung Karees (Kasus Pada Wajib Pajak Orang Pribadi Pada KPP Pratama Bandung Karees)
}

\author{
Oleh: \\ Dwi Anggraeni Saputri \\ Fakultas Bisnis \\ Program Studi Akuntansi Universitas Mitra Indonesia \\ email: dwianggraenisaputri@umitra.ac.id \\ Ela Sulistia \\ Sekolah Administrasi Bisnis dan Keuangan \\ Program Studi Akuntansi Institut Manajemen Telkom \\ email: elasulistia@gmail.com
}

\begin{abstract}
ABSTRAK
Kepatuhan wajib pajak salah satunya dapat dilihat dari jumlah wajib pajak dalam menyampaikan Surat Pemberitahuan (SPT), beberapa faktor yang mempengaruhi kepatuhan wajib pajak yaitu pengetahuan peraturan perpajakan yang dimiliki oleh wajib pajak serta kualitas pelayanan yang diberikan oleh aparat pajak. Tujuan dilakukannya penelitian ini adalah untuk mengetahui seberapa besar pengaruh pengetahuan peraturan perpajakan dan kualitas pelayanan terhadap kepatuhan wajib pajak baik secara parsial maupun secara simultan.

Penelitian ini merupakan penelitian deskriptif verifikatif bersifat kausalitas. Penelitian ini dilakukan di KPP Pratama Bandung Karees. Teknik sampel dilakukan adalah conveniance sampling dengan total sampel terdiri dari 100 orang wajib pajak orang pribadi, 22 orang dari Account Representative (AR), dan 11 orang dari pemeriksa pajak. Pengujian statistik yang digunakan adalah perhitungan korelasi pearson, uji asumsi klasik, koefisien determinasi, analisis regresi berganda, uji hipotesis dengan menggunakan aplikasi SPSS 17,0.

Hasil dari penelitian ini menunjukkan bahwa pengetahuan peraturan perpajakan dan kualitas pelayanan secara simultan berpengaruh signifikan terhadap kepatuhan wajib pajak dengan tingkat koefisien determinasi 19,3\%. Secara parsial pengetahuan peraturan perpajakan berpengaruh signifikan dengan arah negatif, sedangkan kualitas pelayanan tidak berpengaruh signifikan dengan arah negatif terhadap kepatuhan wajib pajak.

Kata kunci: Pengetahuan Peraturan Perpajakan, Kualitas Pelayanan, Kepatuhan Wajib Pajak.
\end{abstract}

\begin{abstract}
One of taxpayer compliance can be seen from the number of taxpayers in conveying (SPT), several factors that affect tax compliance is tax regulation knowledge possessed by the taxpayer as well as the quality of services provided by the tax authorities. The purpose of this study is to determine how much influence the tax regulation knowledge and service quality on tax compliance either partially or simultaneously.

This study is a verification descriptive research with causality characteristic. The research was conducted in KPP Pratama Bandung Karees. Sampling technique that conducted is conveniance sampling with sample total consisted of 100 individual taxpayers, 22 people from the Account Representative (AR), and 11 people from the tax inspectors. The statistic test used is the Pearson correlation calculations, the classical assumption, the coefficient of determination, multiple regression analysis, hypothesis testing using SPSS 17.0.

The results of this study indicate that knowledge of tax regulation and the quality of service simultaneously significant effect on taxpayer compliance with the coefficient of determination $19.3 \%$ level. Partially knowledge of tax regulation effect significantly with the negative direction, whereas there is no significant effect on the quality of service with a negative direction on tax compliance.
\end{abstract}

Keywords: Tax Regulation Knowledge, Quality of Service, Taxpayer Compliance 
Volume 1, Nomor 2, September 2019, pp 26-47. Copyright (C) 2019 JAFTA, Program Studi Magister Akuntansi, Fakultas Ekonomi, Universitas Kristen Maranatha. ISSN: 2654-4636| E-ISSN: 2656-758X https://journal.maranatha.edu/index.php/jafta

\section{Pendahuluan}

\subsection{Latar Belakang Penelitian}

Pajak merupakan sumber utama penerimaan negara disamping penerimaan dari sumber migas dan non migas. Optimalisasi penerimaan pajak dikarenakan semakin meningkatnya kebutuhan dana pembangunan. Pajak bagi pemerintah tidak hanya merupakan sumber pendapatan, tetapi juga merupakan salah satu variabel kebijaksanaan yang digunakan untuk mengatur jalannya perekonomian. Dengan pajak pemerintah dapat mengatur alokasi sumbersumber ekonomi, mengatur laju inflasi, dan sebagainya. Oleh karena itu pajak mempunyai fungsi strategis dalam suatu negara.

Menurut Surat Edaran Direktur Jenderal Pajak Nomor SE-45/PJ/2007 salah satu tujuan pokok reformasi administrasi perpajakan adalah peningkatan kualitas pelayanan kepada Wajib Pajak dan seluruh stakeholder perpajakan. Kualitas pelayanan itu sendiri yaitu pelayanan yang dapat memberikan kepuasan kepada pelanggan dan tetap dalam batas memenuhi standar pelayanan yang dapat dipertanggungjawabkan serta harus dilakukan secara terus-menerus.

Direktur Penyuluhan Pelayanan dan Hubungan Masyarakat Fatimah Azzahra mengatakan akan mengadakan sensus pajak. Menurut Fatimah, di Indonesia terdapat 20 juta orang Wajib Pajak Orang Pribadi yang telah memiliki Nomor Pokok Wajib Pajak (NPWP). Para Wajib Pajak Orang Pribadi yang melapor serta membayar pajak hanya sekitar 8,5 juta orang saja. Ditjen Pajak juga akan memberikan edukasi cara mengisi Surat Pemberitahuan (SPT) tahunan kepada para Wajib Pajak. (kompas.com, 25 September 2011).

Kegiatan penyuluhan kepada masyarakat dengan memberikan edukasi cara mengisi Surat Pemberitahuan (SPT) termasuk cara aparat pajak dalam meningkatkan kualitas pelayanan agar masyarakat merasa dipermudah dalam memenuhi kewajiban membayar pajak sehingga dapat meningkatkan kepatuhan Wajib Pajak. Didukung oleh penelitian yang dilakukan oleh Arum (2012) yang menyatakan bahwa pelayanan Fiskus berpengaruh positif dan signifikan terhadap kepatuhan Wajib Pajak.

Faktor pengetahuan sangat penting dalam membantu Wajib Pajak melaksanakan kewajibannya, khususnya pengetahuan tentang pajak. Seorang Wajib Pajak dikatakan patuh tentunya harus terlebih dahulu mengetahui apa yang menjadi kewajibannya.

Tidak dapat dipungkiri juga bahwa sebagian Wajib Pajak di Indonesia adalah orang-orang menengah ke atas yang berpenghasilan tinggi, berpendidikan tinggi dan seharusnya sudah memiliki pemahaman yang baik tetapi kepatuhan mereka untuk membayar pajak juga masih tergolong lemah. (kompas.com, 30 September 2011).

Apabila Wajib Pajak tidak memiliki dasar pengetahuan perpajakan, maka Wajib Pajak akan mengalami kesulitan dalam mendaftarkan diri, mengisi Surat Pemberitahuan (SPT) dan menyetor pajaknya. Wajib Pajak yang tidak mengetahui tentang pengetahuan pajak akan mengalami kesulitan tentang berapa jumlah pajak yang seharusnya dibayarkan.

Kegiatan penyuluhan juga memiliki andil besar dalam mensukseskan sosialisasi pajak keseluruhan Wajib Pajak. Hal ini tertuang dalam Keputusan Dirjen Pajak Nomor KEP/114/PJ/2005 Tentang Pembentukan Tim Sosialisasi Perpajakan, sehingga Wajib Pajak mengerti dan memahami peraturan perpajakan sehingga meningkatkan kepatuhan perpajakan.

Institusi perpajakan hingga saat ini juga terus mensosialisasikan peraturan perpajakan dengan berbagai macam inovasi untuk meningkatkan pemahaman Wajib Pajak. Dengan pengetahuan perpajakan yang dimiliki oleh Wajib Pajak diharapkan dapat menyampaikan Surat Pemberitahuan (SPT) 
tahunan tepat pada waktunya untuk meningkatkan kepatuhan Wajib Pajak. Didukung penelitian yang dilakukan oleh Supriyati dan Hidayati (2008) penelitian ini menyatakan bahwa variabel pengetahuan perpajakan memiliki pengaruh yang positif dan signifikan terhadap kepatuhan Wajib Pajak.

Menurut Menteri Keuangan Agus Martowardojo, Wajib Pajak Orang Pribadi yang menyerahkan Surat Pemberitahuan (SPT) hanya 8,5 juta Wajib Pajak. Padahal, penduduk yang aktif bekerja ada 110 juta orang. Artinya rasio Surat Pemberitahuan (SPT) terhadap kelompok pekerja aktif itu hanya 7,7 persen. Dengan kata lain memang tingkat kepatuhan Wajib Pajak masih belum memadai. (kompas.com, 30 September 2011).

Data yang dimiliki Ditjen Pajak hingga tahun lalu, yang punya Nomor Pokok Wajib Pajak (NPWP) hanya 24,812 juta. Wajib Pajak itu terdiri dari 22,131 juta Wajib Pajak Orang Pribadi, 2,136 Wajib Pajak Badan dan 545.232 Wajib Pajak Bendaharawan, jadi masih ada 40 juta yang belum bayar pajak. Data Badan Pusat Statistik (BPS) pun terlihat bahwa jumlah usia kerja di Indonesia mencapai 110 juta pekerja, dimana 60 juta masuk golongan di atas Penghasilan Tidak Kena Pajak (PTKP) dan sisanya berpenghasilan di bawah Penghasilan Tidak Kena pajak (PTKP). Seperti diketahui, kenaikan Penghasilan Tidak Kena Pajak (PTKP) tahun ini hampir 53,4\% dari Rp 15,84 juta menjadi Rp 24,3 juta untuk penghasilan per tahunnya. (nasional.kontan.co.id, 7 Mei 2013).

Berdasarkan Pasal 7 Undang-Undang Ketentuan Umum dan Tata Cara Perpajakan Nomor 28 Tahun 2007 menyatakan bahwa Wajib Pajak yang diharuskan menyerahkan Surat Pemberitahuan (SPT) sebaiknya menghindari kemungkinan terkena denda pajak senilai Rp 100.000 per orang. Denda ini bisa dikenakan jika Wajib Pajak Orang Pribadi terlambat menyampaikan Surat Pemberitahuan (SPT) tahunan.
Kepatuhan Wajib Pajak adalah faktor terpenting dalam sistem perpajakan modern tetapi dalam meningkatkan kepatuhan itu tidaklah mudah untuk diwujudkan, tidak sedikit masyarakat yang belum patuh akan pajak dalam hal melakukan pendaftaran menjadi Wajib Pajak sampai ke pembayaran pajak terutang. Banyak sekali alasan yang menjadi penyebabnya seperti rendahnya pengetahuan masyarakat karena kurangnya sosialisasi yang dilakukan dari pihak Aparat Pajak, pandangan negatif masyarakat terhadap Aparat Pajak (Fiskus).

Terdapat contoh kasus yang menunjukkan masih tingginya ketidakpatuhan Wajib Pajak Orang Pribadi terhadap penyelesaian kewajiban perpajakan. Salah satu contoh yaitu terjadi pada Wajib Pajak Orang Pribadi atas nama Drs. ABC (Nama Samaran), berdasarkan putusan pengadilan pajak nomor Put.11075/PP/M.VI/14/2007 menyatakan bahwa berdasarkan perhitungan petugas pajak, terdapat koreksi atas penghasilan netto Drs. ABC sebesar Rp 126.940.000, dimana nilai itu hampir mencapai 4 kali nilai penghasilan netto yang dilaporkan Drs. ABC. Saat dilakukannya pemeriksaan terhadap 2 (dua) jenis usaha yang dimilikinya yaitu usaha perdagangan eceran khusus barang perhiasan dan usaha jasa bengkel mobil, diketahui bahwa nomor nota yang diserahkan kepada petugas pajak tidak urut atau loncat/ada nomor nota yang hilang sehingga hal tersebut membuktikan bahwa pemohon banding melaporkan kegiatan usaha secara tidak wajar. Pada saat kasus ini di bawa ke tingkat Pengadilan Pajak, terdapat temuan bahwa Wajib Pajak dalam menjalankan usahanya tidak menggunakan pembukuan atau pencatatan terhadap penghasilan jasa bengkel dan toko emasnya. Oleh karena itu Majelis berpendapat Peredaran Usaha Drs. ABC untuk Toko Emas adalah sebesar Rp 110.450.000 dengan persentase norma $20 \%$ dan jasa bengkel sebesar Rp 62.000 .000 dengan persentase norma 17,5\% dengan 
JAFTA — Vol. 1 Nomor 2, September (2019)

total penghasilan netto $\mathrm{Rp}$ 32.940.000. (My Tax Profesional: 2007).

Penelitian yang dilakukan oleh Utami, Andi, dan Ayu (2012) menyatakan bahwa pengetahuan peraturan perpajakan dan kualitas pelayanan berpengaruh signifikan terhadap kepatuhan Wajib Pajak dengan arah hubungan positif. Penelitian yang dilakukan oleh Yuli, Saryadi, dan Sari (2010) juga terdapat pengaruh positif dan signifikan antara pengaruh pelayanan Fiskus terhadap kepatuhan Wajib Pajak serta pengaruh pengetahuan perpajakan terhadap kepatuhan perpajakan.

Dalam penelitian ini, peneliti akan menjadikan Wajib Pajak Orang Pribadi yang terdaftar di kawasan Kantor Pelayanan Pajak Pratama Bandung Karees sebagai objek penelitian. Dimana wajib pajak orang pribadi harus melakukan kewajiban perpajakannya dalam menghitung, menyetorkan jumlah Pajak Pertambahan Nilai atau Pajak Penghasilan

Dari data yang penulis dapatkan dari Kantor Pajak Pelayanan Pratama Bandung Karees dalam 3 (tiga) tahun terakhir, tergambar bahwa jumlah Wajib Pajak Orang Pribadi yang melaporkan SPT-nya jauh lebih rendah dari pada jumlah Wajib Pajak Orang Pribadi yang terdaftar setiap tahunnya, dan dari segi tingkat kepatuhan Wajib Pajak juga tergolong rendah. Hal tersebut tersaji dalam tabel 1.1 berikut:

Tabel 1.1. Wajib Pajak Orang Pribadi Terdaftar, Wajib Pajak Orang Pribadi yang Menyampaikan SPT Tahunan, dan Tingkat Kepatuhan Wajib Pajak Orang Pribadi

\begin{tabular}{cccc} 
Tahun & $\begin{array}{c}\text { Wajib Pajak Orang Pribadi } \\
\text { Terdaftar }\end{array}$ & $\begin{array}{c}\text { Wajib Pajak Orang Pribadi yang } \\
\text { Menyampaikan SPT Tahunan }\end{array}$ & $\begin{array}{c}\text { Tingkat Kepatuhan Wajib Pajak Orang } \\
\text { Pribadi }\end{array}$ \\
\hline $\mathbf{2 0 1 0}$ & 63.681 & 32.070 & $48,20 \%$ \\
\hline $\mathbf{2 0 1 1}$ & 83.670 & 37.649 & $43,85 \%$ \\
\hline $\mathbf{2 0 1 2}$ & 70.177 & 39.305 & $55,22 \%$ \\
\hline
\end{tabular}

Dari tabel diatas dapat dilihat peningkatan jumlah Wajib Pajak Orang Pribadi yang terdaftar mengalami peningkatan pada tahun 2011 dan mengalami penurunan kembali pada tahun 2012. Akan tetapi terdapat perbedaan yang sangat signifikan antara jumlah Wajib Pajak yang terdaftar dengan jumlah Surat Pemberitahuan (SPT) yang dilaporkan. Selain itu dari segi kepatuhan Wajib Pajak Orang Pribadi juga menunjukan penurunan pada tahun 2011 dan kenaikan pada tahun 2012.

Berdasarkan uraian di atas, penulis tertarik untuk melakukan penelitian mengenai masalah tersebut dengan judul: "PENGARUH PENGETAHUAN PERATURAN PERPAJAKAN DAN KUALITAS PELAYANAN TERHADAP KEPATUHAN WAJIB PAJAK PADA KANTOR PELAYANAN PAJAK PRATAMA BANDUNG KAREES (Kasus Pada Wajib Pajak
Orang Pribadi Pada KPP Pratama Bandung Karees)."

\subsection{Tujuan Penelitian}

Untuk mengetahui persepsi Wajib Pajak Orang Pribadi atas pengetahuan peraturan perpajakan dan kualitas pelayanan pada Kantor Pelayanan Pajak Pratama Bandung Karees, Untuk mengetahui bagaimana persepsi Petugas Pajak atas kepatuhan Wajib Pajak Orang Pribadi yang terjadi di Kantor Pelayanan Pajak Pratama Bandung Karees, Untuk mengetahui pengaruh persepsi Wajib Pajak atas pengetahuan peraturan perpajakan terhadap kepatuhan Wajib Pajak Orang Pribadi pada Kantor Pelayanan Pajak Pratama Bandung Karees, Untuk mengetahui pengaruh persepsi Wajib Pajak atas kualitas pelayanan terhadap kepatuhan Wajib Pajak Orang Pribadi pada Kantor Pelayanan Pajak Pratama Bandung Karees, Untuk 
JAFTA — Vol. 1 Nomor 2, September (2019)

mengetahui pengaruh antara persepsi Wajib Pajak atas pengetahuan peraturan perpajakan dan kualitas pelayanan terhadap kepatuhan Wajib Pajak Orang Pribadi pada Kantor Pelayanan Pajak Pratama Bandung Karees.

\section{TINJAUAN PUSTAKA DAN LINGKUP PENELITIAN}

\subsection{Definisi Pajak}

Menurut Ketentuan Umum dan Tata Cara Perpajakan Pasal 1 Undang-Undang Nomor 28 Tahun 2007, "Pajak adalah kontribusi Wajib Pajak kepada Negara yang terutang oleh orang pribadi atau badan yang bersifat memaksa berdasarkan undang-undang, dengan tidak mendapatkan imbalan secara langsung dan digunakan untuk keperluan negara bagi sebesarbesarnya kemakmuran rakyat.

Definisi pajak menurut Rahayu (2010:21) beberapa pengertian pajak berdasarkan pendapat para ahli adalah sebagai berikut:

a. Prof. Dr. P. J. A. Andriani merumuskan,

"Pajak adalah iuran kepada negara (yang dapat dipaksakan) yang terutang oleh yang wajib membayarnya menurut peraturan-peraturan dengan tidak mendapat prestasi kembali, yang langsung dapat ditunjuk, dan yang gunanya adalah untuk membiayai pengeluaranpengeluaran umum berhubung dengan tugas negara untuk menyelenggarakan pemerintahan.”

b. Leroy Beaulieu dalam traite de la Science des Finances, menyatakan bahwa ' $L$ ' impot et la contribution, soit directe soit dissimulee, que la puissance publique exige des habitants ou des biens pur subvenir aux depenses $d u$ gouverment." Pajak adalah bantuan, baik secara langsung maupun tidak yang dipaksakan oleh kekuasaan publik dari penduduk atau dari barang, untuk menutupi belanja pemerintah.

c. H. C Adams dalam buku The Science of Finance merumuskan pajak sebagai "contribution from citizen to the public powers."

\subsection{Pengetahuan Peraturan Perpajakan}

Mengetahui dan memahami peraturan perpajakan bagi setiap Wajib Pajak merupakan suatu keharusan. Karena dengan mengetahui dan memahami peraturan perpajakan, seorang Wajib Pajak akan lebih mudah untuk menjalankan kewajiban dalam membayar pajaknya, selain itu jika Wajib Pajak mengetahui dan memahami tentang peraturan perpajakan maka akan terhindar dari sanksi pajak.

Cara mengetahui peraturan perpajakan bagi Wajib Pajak tidaklah sulit, karena pada saat ini media informasi (seperti internet) telah memudahkan setiap Wajib Pajak untuk dapat mengetahui peraturan perpajakan yang terbaru. Selain melalui media informasi, pengetahuan tentang perpajakan dapat diperoleh melalui sosialisasi dari petugas pajak ataupun dengan mengikuti pelatihan pajak.

Setelah Wajib Pajak mengetahui tentang peraturan perpajakan, diharapkan kepada semua Wajib Pajak untuk dapat memahami peraturan perpajakan, sehingga Wajib Pajak dapat lebih mengerti hak dan kewajiban sebagai Wajib Pajak, serta akan memudahkan Wajib Pajak dalam menjalankan kewajiban perpajakannya

\subsection{Kualitas Pelayanan}

Menurut Zain (2007:35), para petugas dari instansi pajak hendaknya dilatih untuk memahami bahwa para Wajib Pajak bukanlah merupakan lawan akan tetapi lebih merupakan anggota masyarakat yang perlu ditolong dalam rangka memenuhi kewajiban perpajakannya atau dengan perkataan lain, rasa hormat-menghormati dan respek hendaknya muncul dari kedua belah pihak.

\subsection{Kepatuhan Wajib Pajak}


JAFTA — Vol. 1 Nomor 2, September (2019)

Menurut Rahayu (2010:139) mengatakan bahwa "kepatuhan WajibPajak adalah tindakan Wajib Pajak yang taat dan memenuhi serta melaksanakan kewajiban perpajakan sesuai dengan ketentuan peraturan perundang-undangan perpajakan.

Menurut Rahayu (2010:149) menyatakan bahwa ada beberapa penyebab Wajib Pajak tidak patuh yaitu:

1. Fitrah penghasilan yang diperoleh Wajib Pajak yang utama ditujukan untuk pemenuhan hidupnya. Pada saat telah memenuhi ketentuan perpajakan timbul kewajiban pembayaran pajak kepada negara. Timbul konflik, antara kepentingan sendiri dan kepentingan negara. Pada umumnya kepentingan pribadi yang selalu dimenangkan.

2. Wajib Pajak kurang sadar tentang kewajiban bernegara, tidak patuh pada peraturan, dan kurang menghargai hukum.

Menurut Rahayu (2010:138), menjelaskan "Ada dua macam kepatuhan yaitu: (1). Kepatuhan formal adalah suatu keadaan dimana wajib pajak memenuhi kewajiban secara formal sesuai dengan ketentuan dalam Undang-Undang Perpajakan. (2). Kepatuhan material adalah suatu keadaan dimana wajib pajak secara substantif atau hakikatnya memenuhi semua ketentuan material perpajakan, yakni sesuai isi dan jiwa Undang-Undang Perpajakan.”।

\section{METODE PENELITIAN}

\subsection{Jenis Penelitian}

Dalam melakukan penelitian ini penulis menggunakan metode deskriptif verifikatif yang bersifat kausalitas. Penelitian deskriptif adalah penelitian yang dilakukan untuk mengetahui dan menjadi mampu untuk menjelaskan karakteristik variabel yang diteliti dalam suatu situasi. Tujuan penelitian deskriptif adalah memberikan kepada peneliti sebuah riwayat atau untuk menggambarkan aspek-aspek yang relevan dengan fenomena perhatian dari persepektif seseorang, organisasi, orientasi industri, atau lainnya. Studi deskriptif menampilkan data dalam bentuk yang bermakna, membantu untuk (1) memahami karakteristik sebuah kelompok dalam situasi tertentu, (2) memikirkan secara sistematis mengenai berbagai aspek dalam situasi tertentu, (3) memberikan gagasan untuk penyelidikan dan penelitian lebih lanjut, dan/atau (4) membuat keputusan tertentu yang sederhana (Sekaran, 2009: 158).

Penelitian ini juga termasuk ke dalam penelitian verifikatif karena bertujuan untuk menguji kebenaran hipotesis yang diajukan. Selain itu, penelitian ini bersifat kausal karena berguna untuk menganalisis hubungan dari suatu variabel (independen) terhadap variabel lain (dependen).

Penelitian verifikatif yang bersifat kausalitas disusun untuk meneliti kemungkinan adanya hubungan sebab akibat antar variabel (Sanusi, 2011: 14).

Dilihat dari pendekatan analisisnya penelitian ini menggunakan jenis data kuantitatif. Data kuantitatif adalah data yang berbentuk angka, atau data kualitatif yang diangkakan (Sugiyono, 2011:223).

\subsection{Operasional Variabel}

Sekaran (2009:115), variabel adalah apapun yang dapat membedakan atau membawa variasi pada nilai. Nilai bisa berbeda pada berbagai waktu untuk objek atau orang yang sama, atau pada waktu yang sama untuk objek atau orang yang berbeda

Dalam penelitian ini, menurut hubungan antara satu variabel dengan variabel yang lain, maka variabel yang digunakan adalah variabel independen (variabel bebas) dan variabel dependen (variabel terikat). 


\subsubsection{Variabel Independen (Variabel Bebas)}

Variabel independen menurut Sekaran (2009: 117), adalah variabel yang mempengaruhi variabel terikat, entah secara positif atau negatif. Jika terdapat variabel bebas, variabel terikat juga hadir, dan dengan setiap unit kenaikan dalam variabel bebas, terdapat pula kenaikan atau penurunan dalam variabel terikat.

Dalam penelitian ini terdapat dua variabel independen yang digunakan yaitu:

\section{Pengetahuan Peraturan Perpajakan $\left(X_{1}\right)$}

Mengetahui dan memahami peraturan perpajakan bagi setiap wajib pajak merupakan suatu keharusan, karena dengan mengetahui dan memahami peraturan perpajakan, seorang wajib pajak akan lebih mudah untuk menjalankan kewajiban dalam membayar pajaknya, selain itu jika wajib pajak mengetahui dan memahami tentang peraturan perpajakan, maka akan terhindar dari sanksi pajak.

\section{Kualitas Pelayanan $\left(\mathbf{X}_{2}\right)$}

Dalam usaha mengembangkan iklim perpajakan yang sehat, ialah mengembangkan dan meningkatkan pelayanan terhadap wajib pajak. Para petugas pada instansi pajak, hendaknya dilatih untuk memahami bahwa para wajib pajak bukanlah merupakan lawan akan tetapi lebih merupakan anggota masyarakat yang perlu ditolong dalam rangka memenuhi kewajiban perpajakannya atau dengan perkataan lain, rasa hormat menghormati hendaknya muncul dari kedua belah pihak.

\subsubsection{Variabel Dependen (Variabel Terikat)}

Menurut Sekaran (2009: 116), "variabel dependen merupakan variabel yang menjadi perhatian utama peneliti. Dengan kata lain, variabel terikat merupakan variabel utama yang menjadi faktor yang berlaku dalam investigasi."

Dalam penelitian ini terdapat satu variabel dependen yang digunakan yaitu:

\section{Kepatuhan Wajib Pajak (Y)}

Kepatuhan Wajib Pajak adalah tindakan wajib pajak dalam pemenuhan kewajiban perpajakannya sesuai dengan ketentuan perundangundangan dan peraturan pelaksanaan perpajakan yang berlaku dalam suatu negara

Tabel 3.1. Operasional Variabel

\begin{tabular}{|c|c|c|c|}
\hline Variabel & Konsep Variabel & Indikator & Skala \\
\hline $\begin{array}{l}\text { Pengetahuan Peraturan } \\
\text { Perpajakan }\left(\mathrm{X}_{1}\right)\end{array}$ & $\begin{array}{l}\text { Mengetahui dan memahami peraturan } \\
\text { perpajakan bagi setiap wajib pajak merupakan } \\
\text { suatu keharusan. Karena dengan mengetahui } \\
\text { dan memahami peraturan perpajakan, seorang } \\
\text { wajib pajak akan lebih mudah untuk } \\
\text { menjalankan kewajiban dalam membayar } \\
\text { pajaknya, selain itu jika wajib pajak mengetahui } \\
\text { dan memahami tentang peraturan perpajakan, } \\
\text { maka akan terhindar dari sanksi pajak. } \\
\text { (Utami, Andi, dan Ayu, 2012) }\end{array}$ & $\begin{array}{l}\text { a. Kepemilikan Nomor Pokok Wajib Pajak (NPWP). } \\
\text { b. Pengetahuan dan pemahaman mengenai hak dan } \\
\text { kewajiban. } \\
\text { c. Pengetahuan dan pemahaman mengenai sanksi } \\
\text { perpajakan. } \\
\text { d. Pengetahuan dan pemahaman mengenai Penghasilan } \\
\text { Tidak Kena Pajak (PTKP), Penghasilan Kena Pajak (PKP), } \\
\text { dan Tarif Pajak. } \\
\text { e. Mengetahui dan memahami peraturan perpajakan } \\
\text { melalui sosialisasi yang dilakukan oleh KPP. } \\
\text { f. Mengetahui dan memahami peraturan pajak melalui } \\
\text { training perpajakan yang mereka ikuti. } \\
\text { (Utami, Andi, dan Ayu, 2012) }\end{array}$ & Ordinal \\
\hline Kualitas Pelayanan $\left(\mathrm{X}_{2}\right)$ & $\begin{array}{l}\text { Pelayanan adalah sentra dan indikator utama } \\
\text { untuk membangun citra Direktorat Jendral Pajak, } \\
\text { sehingga kualitas pelayanan harus terus } \\
\text { menerus ditingkatkan dalam rangka mewujud } \\
\text { harapan dan membangun kepercayaan Wajib } \\
\text { Pajak dan seluruh stakeholder perpajakan } \\
\text { terhadap Direktorat Jendral Pajak. } \\
\text { (Surat Edaran Direktur Jenderal Pajak No. SE- } \\
\text { 45/PJ/2007) }\end{array}$ & $\begin{array}{l}\text { a. Reliability (keandalan). } \\
\text { b. Responsiveness (tanggapan). } \\
\text { c. Assurance (kepastian). } \\
\text { d. Empathy (empati). } \\
\text { e. Tangible (nyata). } \\
\text { (Zeithaml, 2006: 116) }\end{array}$ & Ordinal \\
\hline Kepatuhan Wajib Pajak (Y) & $\begin{array}{l}\text { Kepatuhan Wajib Pajak adalah tindakan Wajib } \\
\text { Pajak yang taat dan memenuhi serta } \\
\text { melaksanakan kewajiban perpajakan sesuai } \\
\text { dengan ketentuan peraturan perundang- } \\
\text { undangan perpajakan. } \\
\text { (Rahayu, 2010) }\end{array}$ & $\begin{array}{l}\text { a. Mengisi formulir pajak dengan lengkap dan jelas. } \\
\text { b. Menghitung jumlah pajak yang terutang dengan benar. } \\
\text { c. Membayar pajak yang terutang tepat pada waktunya. } \\
\text { d. Menyampaikan/melaporkan Surat Pemberitahuan (SPT) } \\
\text { tepat pada waktunya. } \\
\text { (Rahayu, 2010) }\end{array}$ & Ordinal \\
\hline
\end{tabular}


JAFTA — Vol. 1 Nomor 2, September (2019)

\subsection{Populasi Sample}

Populasi menurut Sugiyono (2011:80) adalah wilayah generalisasi yang terdiri atas: obyek/subyek yang mempunyai kualitas dan karakteristik tertentu yang ditetapkan oleh peneliti untuk dipelajari dan kemudian ditarik kesimpulannya. Dalam penelitian ini, populasinya adalah 70.177 dari Wajib Pajak Orang Pribadi yang terdaftar tahun 2012 di KPP Bandung Karees, 22 orang dari Account Representative, dan 11 orang dari Pemeriksa Pajak yang bertugas di KPP Bandung Karees.

Sampel adalah sebagian dari jumlah dan karakteristik yang dimiliki oleh populasi tersebut (Sugiyono, 2011:81). Teknik sampling yang ditetapkan untuk wajib pajak orang pribadi adalah teknik non-probability sampling. Dalam penelitian ini digunakan tingkat kekeliruan pengambilan sampel yang dapat ditolerir sebesar 10\%. Teknik pengambilan sample yang dilakukan untuk menyebar kuesioner kepada Wajib Pajak yaitu dengan cara Conveniance Sampling.

Jumlah sampel dalam penelitian ini adalah sebanyak 133 responden dengan rincian 100 responden dari wajib pajak orang pribadi, 22 responden dari Account Representative (AR) dan 11 responden dari Pemeriksa Pajak.

Karakteristik wajib pajak yang akan dijadikan sampel adalah sebagai berikut:

1. Wajib pajak orang pribadi yang terdaftar di KPP Pratama Karees.

2. Wajib pajak orang pribadi yang menyampaikan Surat Pemberitahuan (SPT) Tahunan di KPP Pratama Karees.

Sedangkan teknik yang digunakan untuk Account Representative dan Pemeriksa Pajak adalah teknik sampling jenuh, hal ini sering dilakukan bila jumlah populasi relatif kecil

\subsection{Teknik Analisis Data}

Metode kualitatif yaitu metode pengolahan data yang dinyatakan dengan kalimat secara deskriptif. Menurut Narimawati (2007:83) langkahlangkah yang dilakukan dalam penelitian kualitatif adalah sebagai berikut :

1. Setiap indikator/subvariabel yang dinilai oleh responden, diklasifikasikan ke dalam lima alternatif jawaban dengan skala ordinal yang menggambarkan peringkat jawaban. Peringkat jawaban setiap indikator diberi skor antara 1 sampai dengan 5.

2. Dihitung total skor setiap variabel/sub variabel $=$ jumlah skor dari seluruh skor indikator variabel untuk semua responden.

3. Dihitung skor setiap variabel/sub variabel = rata-rata dari total skor.

Untuk mendeskripsikan jawaban responden juga digunakan statistik seperti distribusi frekuensi dan ditampilkan dalam bentuk tabel ataupun grafik dengan bantuan software Excell dan SPSS." Untuk menetapkan peringkat dalam setiap variabel penelitian, dapat dilihat dari perbandingan antara skor aktual dan ideal. Skor aktual diperoleh melalui hasil perhitungan seluruh pendapat responden, sedangkan skor ideal diperoleh dari prediksi nilai tertinggi dikalikan dengan jumlah pertanyaan kuesioner

4. dikalikan dengan jumlah responden. Apabila digambarkan dengan rumus, maka akan tampak seperti di bawah ini:

$$
\% \text { skor aktual }=\frac{\text { Skor aktual }}{\text { Skor ideal }} \times 100 \%
$$

Keterangan:

a. Skor aktual adalah jawaban seluruh responden atas kuesioner yang telah diajukan.

b. Skor ideal adalah skor atau bobot tertinggi atau semua responden diasumsikan memilih jawaban dengan skor tertinggi 
JAFTA — Vol. 1 Nomor 2, September (2019)

Tabel 3.2. Kriteria Persentase Tanggapan

\section{Responden}

\begin{tabular}{ccc} 
No. & \% Jumlah Skor & Kriteria \\
\hline 1. & $20.00-36.00$ & Sangat Tidak Baik \\
2. & $36.01-52.00$ & Kurang Baik \\
3. & $52.01-68.00$ & Cukup Baik \\
4. & $68.01-84.00$ & Baik \\
5. & $84.01-100$ & Sangat Baik \\
\hline
\end{tabular}

\section{HASIL PENELITIAN DAN \\ PEMBAHASAN}

\subsection{Karakteristik Responden}

Responden yang ditetapkan oleh penulis bertujuan untuk menganalisis dan mengukur ada atau tidaknya pengaruh dari pengetahuan peraturan perpajakan dan kualitas pelayanan terhadap kepatuhan wajib pajak. Tabel 4.1 menunjukkan karakteristik responden berdasarkan umur, jenis kelamin, jenis pekerjaan, pendidikan terakhir.

Tabel 4.1Karakteristik Responden

\begin{tabular}{|c|c|c|c|c|c|c|c|}
\hline No. & Karakteristik Responden & $\mathbf{F}$ & $\%$ & No. & Karakteristik Responden & $\mathbf{F}$ & $\%$ \\
\hline \multirow[t]{7}{*}{1.} & Berdasarkan Umur WPOP & & & 7. & Berdasarkan Jenis Pekerjaan WPOP & & \\
\hline & $\leq 25$ Tahun & 23 & $23 \%$ & & PNS & 12 & $12 \%$ \\
\hline & $26-35$ Tahun & 36 & $36 \%$ & & Karyawan & 55 & $55 \%$ \\
\hline & $36-45$ Tahun & 23 & $23 \%$ & & Konsultan & 3 & $3 \%$ \\
\hline & $>45$ Tahun & 18 & $18 \%$ & & Wiraswasta & 23 & $23 \%$ \\
\hline & & & & & Pensiunan & 7 & $7 \%$ \\
\hline & Total & 100 & $100 \%$ & & Total & 100 & $100 \%$ \\
\hline \multirow[t]{6}{*}{2.} & Berdasarkan Umur AR & & & 8. & Berdasrkan Jenis Pekerjaan Fiskus & & \\
\hline & $\leq 25$ Tahun & 0 & $0 \%$ & & $\mathrm{AR}$ & 22 & $66,67 \%$ \\
\hline & $26-35$ Tahun & 12 & $54,54 \%$ & & Pemeriksa Pajak & 11 & $33,33 \%$ \\
\hline & $36-45$ Tahun & 9 & $40,91 \%$ & & & & \\
\hline & $>45$ Tahun & 1 & $4,55 \%$ & & & & \\
\hline & Total & 22 & $100 \%$ & & Total & 33 & $100 \%$ \\
\hline \multirow[t]{7}{*}{3.} & Berdasarkan Umur Pemeriksa Pajak & & & 9. & Berdasarkan Pendidikan Terakhir WPOP & & \\
\hline & $\leq 25$ Tahun & 1 & $9,10 \%$ & & SMA & 36 & $36 \%$ \\
\hline & $26-35$ Tahun & 7 & $63,62 \%$ & & D3 & 21 & $21 \%$ \\
\hline & $36-45$ Tahun & 2 & $18,18 \%$ & & $\mathrm{~S} 1$ & 37 & $37 \%$ \\
\hline & $>45$ Tahun & 1 & $9,10 \%$ & & $\mathrm{~S} 2$ & 3 & $3 \%$ \\
\hline & & & & & Lain-lain & 3 & $3 \%$ \\
\hline & Total & 11 & $100 \%$ & & Total & 100 & $100 \%$ \\
\hline \multirow[t]{5}{*}{4.} & Berdasarkan Jenis Kelamin WPOP & & & 10. & Berdasrkan Pendidikan Terakhir AR & & \\
\hline & Laki-laki & 63 & $63 \%$ & & D3 & 3 & $13,60 \%$ \\
\hline & Perempuan & 37 & $37 \%$ & & S1 & 16 & $72,80 \%$ \\
\hline & & & & & $\mathrm{S} 2$ & 3 & $13,60 \%$ \\
\hline & $\begin{array}{r}\text { Total } \\
\end{array}$ & 100 & $100 \%$ & & $\begin{array}{r}\text { Total } \\
\end{array}$ & 22 & $100 \%$ \\
\hline \multirow[t]{5}{*}{5.} & Berdasarkan Jenis Kelamin AR & & & 11. & Berdasarkan Pendidikan Terakhir Pemerik & ajak & \\
\hline & Laki-laki & 14 & $64 \%$ & & D3 & 4 & $36,40 \%$ \\
\hline & Perempuan & 8 & $37 \%$ & & $\mathrm{~S} 1$ & 5 & $45,40 \%$ \\
\hline & & & & & $\mathrm{S} 2$ & 2 & $18,20 \%$ \\
\hline & Total & 22 & $100 \%$ & & Total & 11 & $100 \%$ \\
\hline \multirow[t]{4}{*}{6.} & Berdasarkan Jenis Kelamin Pemeriksa Pajak & & & & & & \\
\hline & Laki-laki & 8 & $73 \%$ & & & & \\
\hline & Perempuan & 3 & $27 \%$ & & & & \\
\hline & Total & 11 & $100 \%$ & & & & \\
\hline
\end{tabular}


JAFTA — Vol. 1 Nomor 2, September (2019)

\subsection{Uji Validitas dan Uji Reliabilitas}

\subsubsection{Uji Validitas}

Uji Validitas digunakan untuk mengukur sah atau validnya kuesioner. Menururt Sugiyono (2011: 267), "Validitas merupakan derajat ketepatan antara data yang terjadi pada objek penelitian dengan daya yang dapat dilaporkan oleh peneliti." Dengan demikian data yang valid adalah data "yang tidak berbeda" antar data yang dilaporkan oleh peneliti dengan data yang sesungguhnya yang terjadi pada objek penelitian.

Tabel 4.2. Hasil Uji Validitas

\begin{tabular}{ccccc} 
Variabel & No. Item & r hitung & r tabel & Kesimpulan \\
\hline Pengetahuan Peraturan Perpajakan & 1 & 0,355 & 0,197 & Valid \\
$\left(\mathrm{X}_{1}\right)$ & 2 & 0,287 & 0,197 & Valid \\
& 3 & 0,485 & 0,197 & Valid \\
& 4 & 0,568 & 0,197 & Valid \\
& 5 & 0,512 & 0,197 & Valid \\
& 6 & 0,492 & 0,197 & Valid \\
\hline Kualitas Pelayanan & 1 & 0,46 & 0,197 & Valid \\
$\left(\mathrm{X}_{2}\right)$ & 2 & 0,5 & 0,197 & Valid \\
& 3 & 0,695 & 0,197 & Valid \\
& 4 & 0,711 & 0,197 & Valid \\
& 5 & 0,386 & 0,197 & Valid \\
& 6 & 0,702 & 0,197 & Valid \\
& 7 & 0,527 & 0,197 & Valid \\
& 8 & 0,593 & 0,197 & Valid \\
& 9 & 0,476 & 0,197 & Valid \\
& 10 & 0,562 & 0,197 & Valid \\
\hline Kepatuhan Wajib Pajak & 1 & 0,649 & 0,344 & Valid \\
(Y) & 2 & 0,741 & 0,344 & Valid \\
& 3 & 0,677 & 0,344 & Valid \\
& 4 & 0,481 & 0,344 & Valid \\
\hline & & & &
\end{tabular}

Keterangan :

*) = Dapat dikatakan valid apabila $\mathrm{r}$ hitung lebih besar dari $\mathrm{r}$ tabel 
JAFTA — Vol. 1 Nomor 2, September (2019)

\subsubsection{Uji Reliabilitas}

Menurut Sugiyono(2011) "Reliabilitas adalah derajat konsistensi atau keajegan data dalam interval waktu tertentu." Pengukuran reliabilitas dalam penelitian ini adalah one shot atau pengukuran sekali saja. Pengukuran keandalan butir pertanyaan dengan sekali menyebarkan kuesioner pada responden, kemudian hasil skornya diukur korelasinya antar skor jawaban pada butir pertanyaan yang sama dengan bantuan software SPSS 17.0, dengan fasilitas Cronbach's Alpha ( $\alpha$ ). Suatu konstruk atau variabel dikatakan reliabel jika memberikan nilai Cronbach's Alpha >0,60

\section{Tabel 4.3. Hasil Uji Reliabilitas}

\begin{tabular}{clrl} 
No. & \multicolumn{1}{c}{ Variabel } & $\begin{array}{r}\text { Cronbach' } \\
\text { s.Alpha }\end{array}$ & Kesimpulan \\
\hline $\mathbf{1}$ & $\begin{array}{l}\text { Pengetahuan Peraturan Perpajakan } \\
\left.\text { (variabel } \mathrm{X}_{1}\right)\end{array}$ & 0,713 & Reliabel \\
$\mathbf{2}$ & $\begin{array}{l}\text { Kualitas Pelayanan } \\
\left.\text { (variabel } \mathrm{X}_{2}\right)\end{array}$ & 0,856 & Reliabel \\
$\mathbf{3}$ & $\begin{array}{l}\text { Kepatuhan Wajib Pajak } \\
\text { (variabel Y) }\end{array}$ & 0,815 & Reliabel \\
\hline
\end{tabular}

Keterangan :

*) = Dapat dikatakan reliabel apabila nilai Cronbach Alpha $>0,60$

\subsection{Analisis Deskriptif}

Pada bagian ini akan dijelaskan hasil penelitian yang diperoleh dengan memberikan penilaian atas jawaban responden dalam menetapkan peringkat dalam Pengetahuan Peraturan Perpajakan, Kualitas Pelayanan, dan Kepatuhan Wajib Pajak dapat dilihat dari perbandingan antara skor aktual dengan skor ideal sebagai berikut:

$$
\% \text { Skor Aktual }=\frac{\text { Skor Aktual }}{\text { Skor Ideal }} \times 100 \%
$$

\section{Keterangan:}

a. Skor aktual adalah jawaban seluruh responden atas kuesioner yang telah diajukan

b. Skor ideal adalah skor atau bobot tertinggi atau semua responden diasumsikan memilih jawaban dengan skor tertinggi.

Dengan kriteria berdasarkan tabel berikut: 
Tabel 4.4. Kriteria Skor Jawaban Responden Berdasarkan Persentase Skor Aktual

\begin{tabular}{ccc} 
No. & Persentase Skor & Kategori Skor \\
\hline 1. & $20,00-36,00$ & Sangat Tidak Baik \\
2. & $36,01-52,00$ & Kurang Baik \\
3. & $52,01-68,00$ & Cukup Baik \\
4. & $68,01-84,00$ & Baik \\
5. & $84,01-100$ & Sangat Baik \\
\hline
\end{tabular}

a. Pembahasan Analisis Deskriptif Pengetahuan Peraturan Perpajakan

Tabel 4.5. Rekapitulasi PersentaseTotal SkorTanggapan RespondenMengenai Pengetahuan Peraturan Perpajakan pada KPP Pratama BandungKarees

\begin{tabular}{|c|c|c|c|c|c|}
\hline No. & Indikator & $\begin{array}{c}\text { Skor } \\
\text { Aktual }\end{array}$ & Skor Ideal & $\begin{array}{l}\% \text { Skor } \\
\text { Aktual }\end{array}$ & Kriteris \\
\hline 1 & $\begin{array}{l}\text { Kepemilikan Nomor Pokok Wajib } \\
\text { Pajak (NPWP). }\end{array}$ & 436 & 500 & 87,2 & $\begin{array}{l}\text { Sangat } \\
\text { Baik }\end{array}$ \\
\hline 2 & $\begin{array}{l}\text { Pengetahuan dan pemahaman } \\
\text { mengenai hak dan kewajiban. }\end{array}$ & 440 & 500 & 88 & $\begin{array}{l}\text { Sangat } \\
\text { Baik }\end{array}$ \\
\hline 3 & $\begin{array}{l}\text { Pengetahuan dan pemahaman } \\
\text { mengenai sanksi perpajakan. }\end{array}$ & 408 & 500 & 81,6 & Baik \\
\hline 4 & $\begin{array}{l}\text { Pengetahuan dan pemahaman } \\
\text { mengenai PTKP, PKP, dan Tarif Pajak. }\end{array}$ & 399 & 500 & 79,8 & Baik \\
\hline 5 & $\begin{array}{l}\text { Mengetahui dan memahami peraturan } \\
\text { perpajakan melalui sosialisasi yang } \\
\text { dilakukan oleh KPP. }\end{array}$ & 411 & 500 & 82,2 & Baik \\
\hline 6 & $\begin{array}{l}\text { Mengetahui dan memahami peraturan } \\
\text { pajak melalui training perpajakan yang } \\
\text { mereka ikuti. }\end{array}$ & 424 & 500 & 84,8 & $\begin{array}{l}\text { Sangat } \\
\text { Baik }\end{array}$ \\
\hline & Total & 2518 & 3000 & 83,93 & Baik \\
\hline
\end{tabular}

Berdasarkan tabel rekapitulasi persentase total skor tanggapan responden mengenai Pengetahuan Peraturan Perpajakan diatas, dapat dilihat bahwa Pengetahuan Peraturan Perpajakan pada KPP Pratama Bandung Karees berada pada kategori
Baik yaitu sebesar 83,93\%. Artinya, Wajib Pajak Orang Pribadi menilai bahwa Pengetahuan Peraturan Perpajakan baik untuk pemenuhan kepatuhan Wajib Pajak.

b. Pembahasan Analisis Deskriptif Kualitas Pelayanan 
JAFTA - Vol. 1 Nomor 2, September (2019)

Tabel 4.6. Rekapitulasi PersentaseTotal SkorTanggapan RespondenMengenai Kualitas Pelayanan pada KPP Pratama Bandung Karees

\begin{tabular}{clcccc} 
No. & \multicolumn{1}{c}{ Indikator } & $\begin{array}{c}\text { Skor } \\
\text { Aktual }\end{array}$ & Skor Ideal & $\begin{array}{c}\text { \% Skor } \\
\text { Aktual }\end{array}$ & Kriteria \\
\hline 1 & Reliability (keandalan) & 823 & 1000 & 82,3 & Baik \\
2 & Responsiveness (tanggapan) & 799 & 1000 & 79,9 & Baik \\
3 & Assurance (kepastian) & 747 & 1000 & 74,7 & Baik \\
4 & Empathy (empati) & 749 & 1000 & 74,9 & Baik \\
5 & Tangible (nyata) & 784 & 1000 & 78,4 & Baik \\
\hline & Total & $\mathbf{3 9 0 2}$ & $\mathbf{5 0 0 0}$ & $\mathbf{7 8 , 0 4}$ & Baik \\
\hline
\end{tabular}

Berdasarkan tabel rekapitulasi persentase total skor tanggapan responden mengenai kualitas pelayanan diatas, dapat dilihat bahwa kualitas pelayanan pada KPP Pratama Bandung Karees berada pada kategori baik yaitu sebesar 78,04\%. Artinya, kualitas pelayanan telah baik dalam menjalankan tugasnya untuk pemenuhan kepatuhan Wajib Pajak.
Sehingga dengan kualitas pelayanan yang baik diharapkan Wajib Pajak Orang pribadi tidak akan melakukan pelanggaran dan memenuhi kewajiban perpajakan sesuai dengan ketentuan yang berlaku

b. Pembahasan Analisis Deskriptif Kepatuhan Wajib Pajak

Tabel 4.7. Rekapitulasi Persentase Total Skor Tanggapan Responden Mengenai Kepatuhan Wajib Pajak di KPP Pratama Bandung Karees

\begin{tabular}{clcccc} 
No. & \multicolumn{1}{c}{ Indikator } & $\begin{array}{c}\text { Skor } \\
\text { Aktual }\end{array}$ & Skor Ideal & $\begin{array}{c}\text { \% Skor } \\
\text { Aktual }\end{array}$ & Kriteria \\
\hline 1. & $\begin{array}{l}\text { Mengisi formulir pajak dengan lengkap } \\
\text { dan jelas. } \\
\text { Menghitung jumlah pajak yang terutang }\end{array}$ & 101 & 165 & 61,21 & Cukup Baik \\
2. & $\begin{array}{l}\text { dengan benar. } \\
\text { Membayar pajak yang terutang tepat pada }\end{array}$ & 101 & 165 & 55,15 & Cukup Baik \\
3. & $\begin{array}{l}\text { Maktunya. } \\
\text { Menyampaikan/ melaporkan Surat }\end{array}$ & 95 & 165 & 57,57 & Cukup Baik \\
4. & $\begin{array}{l}\text { Pemberitahuan (SPT) tepat pada waktunya. } \\
\text { Total }\end{array}$ & $\mathbf{3 8 8}$ & $\mathbf{6 6 0}$ & $\mathbf{5 8 , 7 8}$ & Cukup Baik \\
\hline
\end{tabular}

Berdasarkan tabel rekapitulasi persentase total skor tanggapan responden mengenai kepatuhan Wajib Pajak diatas, dapat dilihat bahwa tingkat kepatuhan Wajib Pajak Orang Pribadi pada KPP Pratama Bandung Karees berada pada kategori Cukup Baik sebesar 58,78\%. Artinya, Wajib Pajak Orang Pribadi telah mematuhi kewajiban perpajakannya

\subsection{Uji Asumsi Klasik}

\subsubsection{Uji Normalitas}

Uji normalitas pada model regresi digunakan untuk menguji apakah nilai residual terdistribusi secara normal atau tidak. Pengujian normalitas pada penelitian ini dilakukan dengan uji statistik Normal P-P Plot Regression Standardized Residual. Pada 
JAFTA — Vol. 1 Nomor 2, September (2019)

prinsipnya normalitas dapat dideteksi dengan melihat penyebaran data (titik) pada sumbu diagonal dari grafik atau dengan melihat histogram dari residualnya.

\section{Gambar 4.1. Uji Normalitas}

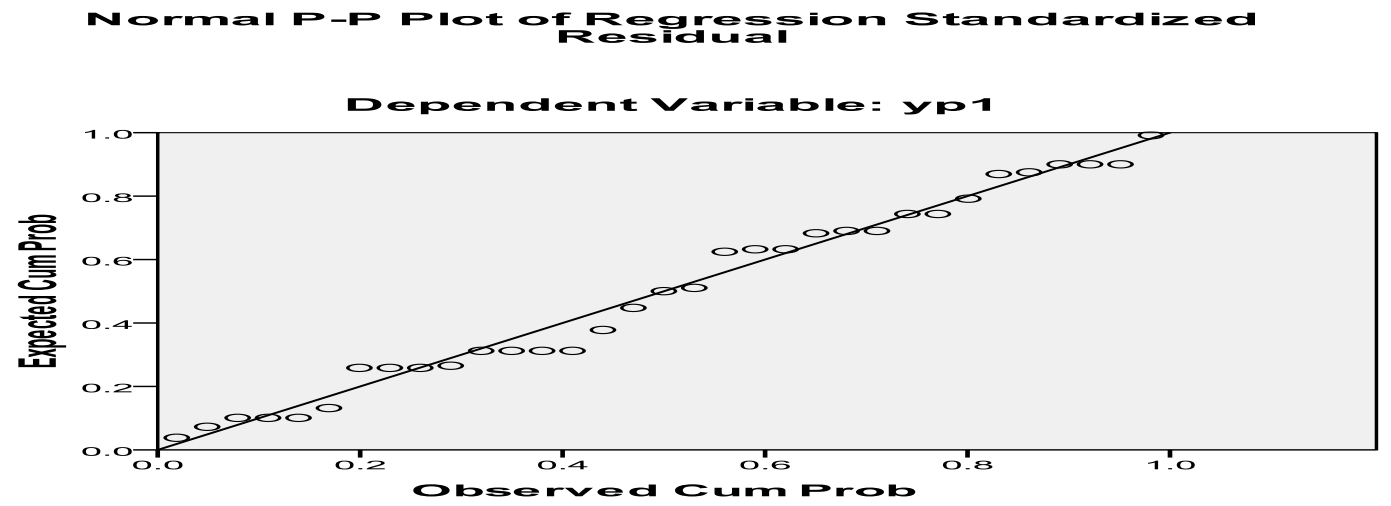

Berdasarkan gambar 4.1 diatas, dapat diketahui bahwa jika pada grafik normal plot terlihat titiktitik menyebar disekitar garis diagonal dan mengikuti arah garis diagonal atau grafik histogramnya menunjukan pola distribusi normal, maka model regresi memenuhi asumsi normalitas. Oleh karena itu, dapat disimpulkan bahwa variabel Pengetahuan Peraturan Perpajakan $\left(\mathrm{X}_{1}\right)$ dan Kualitas Pelayanan $\left(\mathrm{X}_{2}\right)$ terhadap Kepatuhan Wajib Pajak (Y) berdistribusi secara normal.

\subsubsection{Uji Heteroskedasitas}

Menurut Sunyoto (2008: 82), uji ini digunakan untuk menentukan ada atau tidaknya varians dari residual dari observasi yang satu dengan observasi yang lain. Uji heteroskedasitas dilakukan dengan melihat hasil output SPSS melalui grafik scatterplot antara Z prediction (ZPRED) yang merupakan variabel bebas (sumbu $\mathrm{X}=\mathrm{Y}$ hasil prediksi) dan nilai residualnya (SRESID) merupakan variabel terikat (sumbu $\mathrm{Y}=\mathrm{Y}$ prediksi $-\mathrm{Y}$ riil). Model regresi dikatakan baik apabila terjadi homokedasitas atau tidak terjadi heterokedasitas.

\section{Gambar 4.2. Uji Heteroskedasitas}

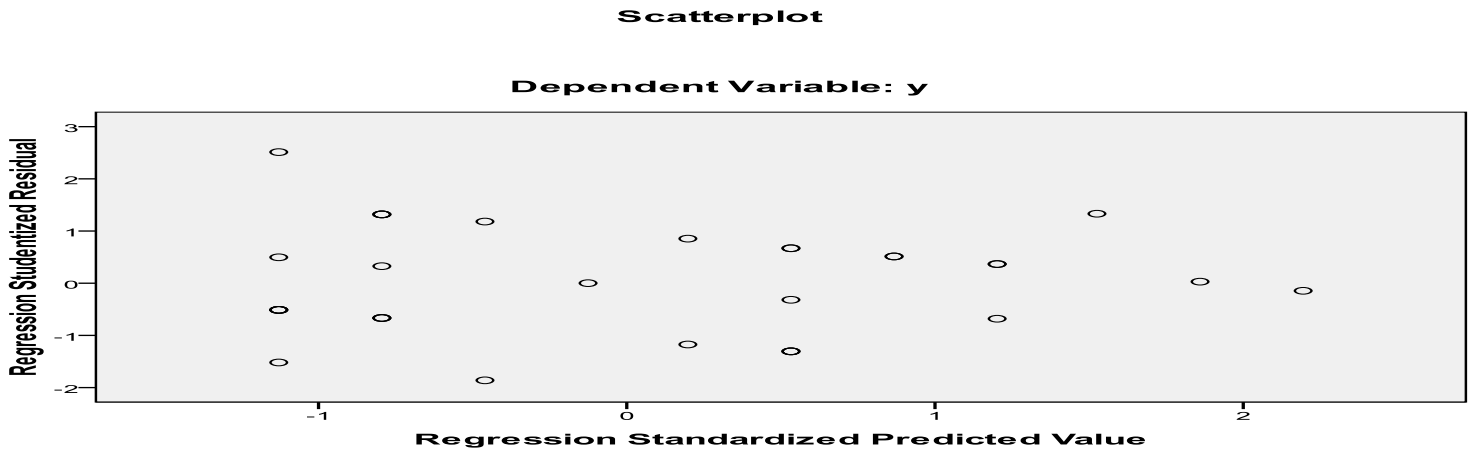

Grafik scatterplot pada gambar 4.13 memperlihatkan bahwa titik-titik menyebar secara acak serta tersebar baik di atas maupun di bawah angka 0 pada sumbu Y. Dapat ditarik kesimpulan bahwa tidak terjadi Heterokedastisitas pada model regresi linier sederhana yang digunakan, sehingga model regresi layak dipakai untuk mengetahui Kepatuhan Wajib Pajak pada KPP Pratama 
JAFTA — Vol. 1 Nomor 2, September (2019)

Bandung Karees berdasarkan variabel independen yaitu Pengetahuan Peraturan Perpajakan dan Kualitas Pelayanan.

\subsubsection{Uji Multikolinearitas}

Uji multikolinieritas bertujuan untuk menguji apakah model regresi linier berganda ditemukan adanya korelasi antar variabel independen. Model regresi yang baik seharusnya tidak terjadi korelasi antara variabel independen. Nilai yang umum dipakai untuk menunjukkan adanya multikolinieritas adalah VIF > 10 dan Tolerance< 0.1 .

Tabel 4.8. Uji Multikolinearitas

\begin{tabular}{clcc} 
Model & & Tolerance & VIF \\
\hline & (Constant) & & \\
$1 \mathrm{X} 1$ & .958 & 1.044 \\
$\mathrm{X} 2$ & .958 & 1.044 \\
\hline
\end{tabular}

Berdasarkan tabel 4.8 diatas, hasil nilai tolerance menujukkan tidak ada variabel independen yaitu Pengetahuan Peraturan Perpajakan $\left(\mathrm{X}_{1}\right)$ dan Kualitas Pelayanan $\left(\mathrm{X}_{2}\right)$ yang memiliki nilai tolerance kurang dari 0,10 yang berarti tidak ada kolerasi antara variabel independen. Hasil nilai VIF juga menunjukkan hal yang sama, tidak ada variabel independen Pengetahuan Peraturan Perpajakan $\left(\mathrm{X}_{1}\right)$ dan Kualitas Pelayanan $\left(\mathrm{X}_{2}\right)$ yang memiliki nilai VIF lebih dari 10. Jadi dapat disimpulkan bahwa tidak ada multikolonieritas antarvariabel independen dalam persamaan regresi pada penelitian ini.

\subsection{Analisis Koefisien determinasi $\left(\mathbf{R}^{2}\right)$}

Pengujian koefisien determinasi dilakukan untuk mengukur persentase pengaruh variabel independen terhadap perubahan variabel dependen. Koefisien determinan berkisar antara nol sampai dengan satu $\left(0 \leq \mathrm{R}^{2} \leq 1\right)$. Bila $\mathrm{R}^{2}=0$ menunjukkan tidak adanya pengaruh antara variabel independen terhadap variabel dependen. Bila $R$ square semakin mendekati 1 menunjukkan semakin kuatnya pengaruh variabel independen terhadap variabel dependen dan bila $R$ square semakin mendekati nol maka semakin kecil pengaruh variabel independen terhadap variabel dependen.

Tabel 4.9. Koefisien Determinasi

\begin{tabular}{|c|c|c|c|c|}
\hline \multicolumn{5}{|c|}{ Model Summary ${ }^{\text {b }}$} \\
\hline Model & $\mathrm{R}$ & R Square & $\begin{array}{l}\text { Adjusted } \\
\text { R Square }\end{array}$ & $\begin{array}{l}\text { Std. Error } \\
\text { of the } \\
\text { Estimate }\end{array}$ \\
\hline 1 & $.439^{\mathrm{a}}$ & .193 & .139 & 103.585 \\
\hline
\end{tabular}


JAFTA — Vol. 1 Nomor 2, September (2019)

Pada tabel 4.9 menunjukan bahwa koefisien determinasi diperoleh nilai $R$ Square sebesar 0,193. Hal ini berarti bahwa 19,3\% variabel dependen yaitu Kepatuhan Wajib Pajak dapat dipengaruhi oleh variabel independen yaitu Pengetahuan Peraturan Perpajakan dan Kualitas Pelayanan, sedangkan sisanya sebesar $80,7 \%$ dapat dipengaruhi oleh variabel atau faktor-faktor lain di luar variabel penelitian.

\subsection{Analisis Regresi}

Teknik analisis yang digunakan dalam penelitian ini adalah regresi linier berganda (multiple regression analysis) dalam melakukan pengujian hipotesis. Analisis ini digunakan untuk menguji apakah hipotesis penelitian signifikan atau tidak
Analisis ini untuk menguji variabel independen, dimana dalam penelitian ini adalah Pengetahuan Peraturan Perpajakan dan Kualitas Pelayanan dalam mempengaruhi variabel dependen yaitu Kepatuhan Wajib Pajak. Secara sistematik persamaan tersebut dirumuskan sebagai berikut:

$$
Y=\alpha+\beta_{1} X_{1}+\beta_{2} X_{2}
$$

Keterangan:

$$
\begin{aligned}
& \mathrm{Y}=\text { Kepatuhan Wajib Pajak } \\
& \alpha \quad=\text { Konstanta (tetap) } \\
& \beta_{1}, \beta_{2}=\text { Koefisien Regresi } \\
& X_{1} \quad=\text { Pengetahuan Peraturan Perpajakan } \\
& X_{2} \quad=\text { Kualitas Pelayanan }
\end{aligned}
$$

\begin{tabular}{|c|c|c|c|c|c|}
\hline \multicolumn{6}{|c|}{ Coefficients $^{\mathrm{a}}$} \\
\hline \multirow{4}{*}{ Model } & \multirow{4}{*}{\multicolumn{3}{|c|}{$\begin{array}{cc}\text { Adardized } & \text { Standardiz } \\
\text { ficients } & \text { ed } \\
& \text { Coefficient } \\
& s \\
\text { Std. Error } & \text { Beta }\end{array}$}} & \multirow{4}{*}{$\mathrm{T}$} & \multirow{4}{*}{ Sig. } \\
\hline & & & & & \\
\hline & & & & & \\
\hline & & & & & \\
\hline (Constant) & 6.580 & 1.329 & & 4.951 & .000 \\
\hline $1 \mathrm{x} 1 \mathrm{p} 1$ & -.651 & .282 & -.386 & -2.305 & .028 \\
\hline $\mathrm{x} 2 \mathrm{p} 1$ & -.164 & .191 & -.144 & -.859 & .397 \\
\hline
\end{tabular}

Dengan menggunakan software SPSS, diperoleh hasil analisis regresi linier berganda sesuai dengan tabel 4.10 berikut

Tabel 4.10. Koefisien Regresi Berganda

a. Dependent Variable: yp 1

Berdasarkan hasil output pada tabel 4.10 diperoleh nilai $\alpha$ (konstanta) sebesar 6,580, nilai $\beta_{1}$ sebesar 0,651 dan $\beta_{2}$ sebesar -0,164. Dengan demikian dapat dibentuk persamaan regresi linier berganda sebagai berikut:

$$
\begin{aligned}
\mathrm{Y}= & 6,580-0,651 \mathrm{X}_{1}-0,164 \mathrm{X}_{2} \\
\text { Berdasarkan } & \text { persamaan di atas dapat }
\end{aligned}
$$
diinterpretasikan sebagai berikut:

1. Konstanta sebesar 6,580 menyatakan bahwa jika variabel Pengetahuan Peraturan Perpajakan $\left(\mathrm{X}_{1}\right)$ dan Kualitas Pelayanan $\left(\mathrm{X}_{2}\right)$ bernilai 0 maka Kepatuhan Wajib Pajak pada KPP Pratama
Bandung Karees akan bernilai positif dengan nilai 6,580 .

2. Koefisien regresi Pengetahuan Peraturan Perpajakan $\left(\mathrm{X}_{1}\right)$ bernilai negatif sebesar $-0,651$ menyatakan bahwa jika Pengetahuan Peraturan Perpajakan meningkat sebesar 1 satuan dan variabel lainnya konstan, maka Kepatuhan Wajib Pajak Orang Pribadi pada KPP Pratama Bandung Karees akan menurun sebesar -0,651 satuan.

3. Koefisien regresi Kualitas Pelayanan $\left(X_{2}\right)$ bernilai negatif sebesar -0,164 menyatakan 
JAFTA — Vol. 1 Nomor 2, September (2019)

bahwa jika Kualitas Pelayanan meningkat sebesar 1 satuan dan variabel lainnya konstan, maka Kepatuhan Wajib Pajak Orang Pribadi pada KPP Pratama Bandung Karees akan menurun sebesar $-0,164$ satuan.

\subsection{Uji Hipotesis}

\subsubsection{Uji T (pengaruh secara Parsial)}

Uji statistik t pada dasarnya menunjukkan seberapa jauh pengaruh satu variabel penjelas atau independen secara individual dalam menerangkan variasi variabel dependen (Ghozali, 2011:98). Uji t dilakukan dengan cara melihat nilai signifikan. Dasar pengambilan keputusan dirumuskan sebagai berikut:

a. Jika signifikansi dasar pengambilan keputusannya adalah > 0,05 maka $\mathrm{H}_{\mathrm{o}}$ diterima. b. Jika signifikansi dasar pengambilan keputusannya adalah $<0,05$ maka $\mathrm{H}_{\mathrm{o}}$ ditolak.

Hipotesis secara parsial dalam penelitian ini adalah sebagai berikut:

- Ho1: Pengetahuan Peraturan Perpajakan tidak mempunyai pengaruh secara signifikan terhadap Kepatuhan Wajib Pajak.

- $\mathrm{Ha}_{1}$ : Pengetahuan Peraturan Perpajakan mempunyai pengaruh terhadap Kepatuhan Wajib Pajak.

- $\mathrm{Ho}_{2}$ : Kualitas Pelayanan tidak mempunyai pengaruh secara signifikan terhadap Kepatuhan Wajib Pajak.

- $\mathrm{Ha}_{2}$ : Kualitas Pelayanan mempunyai pengaruh terhadap Kepatuhan Wajib Pajak.

Tabel 4.11 Uji Signifikansi Parsial (Uji T)

\begin{tabular}{|c|c|c|c|c|c|c|}
\hline \multicolumn{7}{|c|}{ Coefficients $^{\mathrm{a}}$} \\
\hline & \multirow{4}{*}{ Model } & \multirow{4}{*}{\multicolumn{3}{|c|}{$\begin{array}{cc}\text { Adardized } & \text { Standardiz } \\
\text { ficients } & \text { ed } \\
& \text { Coefficient } \\
\text { Std. Error } & \text { Beta }\end{array}$}} & \multirow{4}{*}{$\mathrm{T}$} & \multirow{4}{*}{ Sig. } \\
\hline & & & & & & \\
\hline & & & & & & \\
\hline & & & & & & \\
\hline \multirow{3}{*}{1} & (Constant) & 6.580 & 1.329 & & 4.951 & .000 \\
\hline & $\mathrm{x} 1 \mathrm{p} 1$ & -.651 & .282 & -.386 & -2.305 & .028 \\
\hline & $\mathrm{x} 2 \mathrm{p} 1$ & -.164 & .191 & -.144 & -.859 & .397 \\
\hline
\end{tabular}

a. Dependent Variable: yp 1

Berdasarkan tabel 4.11 di atas, dapat diketahui nilai signifikansi pada variabel Pengetahuan Peraturan Perpajakan $\left(\mathrm{X}_{1}\right)$ lebih kecil dari 0,05 yaitu sebesar 0,028. Sehingga dapat disimpulkan bahwa $\mathrm{Ho}_{1}$ ditolak dan $\mathrm{Ha}_{1}$ diterima. Artinya Pengetahuan Peraturan Perpajakan mempunyai pengaruh signifikan terhadap Kepatuhan Wajib Pajak.

Selain itu, berdasarkan tabel 4.11 di atas, dapat diketahui nilai signifikansi pada variabel Kualitas Pelayanan $\left(\mathrm{X}_{2}\right)$ lebih besar dari 0,05 yaitu sebesar 0,397. Sehingga dapat disimpulkan bahwa
$\mathrm{Ho}_{2}$ diterima dan $\mathrm{Ha}_{2}$ ditolak. Artinya Kualitas Pelayanan tidak mempunyai pengaruh signifikan terhadap Kepatuhan Wajib Pajak.

\subsubsection{Uji F (Pengujian secara simultan)}

Uji regresi simultan (Uji F) merupakan pengujian yang digunakan untuk mengetahui ada tidaknya pengaruh bersama-sama antara variabel independen dan variabel dependen. (Ghozalli, 2011:120). 
JAFTA — Vol. 1 Nomor 2, September (2019)

Adapun pengujian hipotesis yang dilakukan dalam penelitian ini dirumuskan sebagai berikut:

a. Jika nilai probabilitas $\mathrm{t}$ hitung $<0,05$ maka ada pengaruh yang kuat antara variabel independen dengan variabel dependen.

b. Jika nilai probabilitas signifikansi t hitung > 0,05 maka tidak ada pengaruh yang kuat antara variabel independen dengan variabel dependen.
Hipotesis secara simultan dalam penelitian ini adalah sebagai berikut:

- Ho: Pengetahuan Peraturan Perpajakan dan Kualitas Pelayanantidak mempunyai pengaruh secara signifikan terhadap Kepatuhan Wajib Pajak.

- Ha: Pengetahuan Peraturan Perpajakan dan Kualitas Pelayanan mempunyai pengaruh terhadap Kepatuhan Wajib Pajak.

Tabel 4.12. Uji Signifikansi Simultan (Uji F)

\begin{tabular}{|c|c|c|c|c|c|c|}
\hline \multicolumn{7}{|c|}{ ANOVA $^{b}$} \\
\hline Model & & $\begin{array}{c}\text { Sum of } \\
\text { Squares }\end{array}$ & Df & $\begin{array}{l}\text { Mean } \\
\text { Square }\end{array}$ & F & Sig. \\
\hline & $\begin{array}{l}\text { Regressio } \\
\mathrm{n}\end{array}$ & 7.689 & 2 & 3.845 & 3.583 & $.040^{\mathrm{a}}$ \\
\hline & ${ }^{1}$ Residual & 32.189 & 30 & 1.073 & & \\
\hline & Total & 39.879 & 32 & & & \\
\hline
\end{tabular}

a. Predictors: (Constant), $\mathrm{x} 2 \mathrm{p} 1, \mathrm{x} 1 \mathrm{p} 1$

\section{b. Dependent Variable: yp1}

Berdasarkan tabel 4.12 dapat diketahui nilai $\mathrm{F}$ hitung sebesar 3,583dengan signifikansi sebesar 0,040. Karena probabilitas lebih kecil dari 0,05 makan dapat disimpulkan bahwa $\mathrm{H}_{\mathrm{o}}$ ditolak dan $\mathrm{H}_{\mathrm{a}}$ diterima. Artinya, Pengetahuan Peraturan Perpajakan dan Kualitas Pelayanan mempunyai pengaruh signifikan terhadap Kepatuhan Wajib Pajak

\section{KESIMPULAN DAN SARAN}

\subsection{Kesimpulan}

Berdasarkan hasil penelitian dan pembahasan mengenai pengaruh Pengetahuan Peraturan Perpajakan dan Kualitas Pelayanan terhadap Kepatuhan Wajib Pajak pada Kantor Pelayanan Pajak (KPP) Pratama Bandung Karees dapat ditarik kesimpulan sebagai berikut:

1. Pengetahuan Peraturan Perpajakan pada Kantor Pelayanan Pajak Pratama Bandung Karees secara umum berada dalam kategori baik.
Artinya sudah memenuhi 6 indikator, yaitu Kepemilikan Nomor Pokok Wajib Pajak (NPWP), Pengetahuan dan pemahaman mengenai hak dan kewajiban, Pengetahuan dan pemahaman mengenai sanksi perpajakan, Pengetahuan dan pemahaman mengenai Penghasilan Tidak Kena Pajak (PTKP), Penghasilan Kena Pajak (PKP), dan Tarif Pajak, Mengetahui dan memahami peraturan perpajakan melalui sosialisasi yang dilakukan oleh KPP, Mengetahui dan memahami peraturan pajak melalui training perpajakan yang mereka ikuti.

Kualitas Pelayanan pada KPP Pratama Bandung Karees secara umum berada dalam kategori baik. Artinya sudah memenuhi 5 indikator, yaitu Tangibles, Emphaty, Realibilty, Responsiveness dan Assurance yang masingmasing indikator menunjukkan tingkat tanggapan pada kondisi baik. 
JAFTA — Vol. 1 Nomor 2, September (2019)

Kepatuhan Wajib Pajak pada KPP

Pratama Bandung Karees secara umum berada dalam kategori cukup baik. Artinya sudah memenuhi 4 indikator, yaitu mengisi formulir pajak dengan lengkap dan jelas, menghitung jumlah pajak yang terutang dengan benar, membayar pajak yang terutang tepat pada waktunya, menyampaikan atau melaporkan Surat Pemberitahuan (SPT) tepat pada waktunya yang masing-masing indikator menunjukkan tingkat tanggapan pada kondisi cukup baik.

2. Berdasarkan hasil pengujian hipotesis secara parsial, diketahui bahwa:

a. Pengetahuan Peraturan Perpajakan berpengaruh signifikan terhadap Kepatuhan Wajib Pajak pada KPP Pratama Bandung Karees.

b. Kualitas Pelayanan tidak berpengaruh signifikan terhadap Kepatuhan Wajib Pajak pada KPP Pratama Bandung Karees.

3. Berdasarkan hasil pengujian hipotesis secara simultan diketahui bahwa Pengetahuan Peraturan Perpajakan dan Kualitas Pelayanan berpengaruh signifikan terhadap Kepatuhan Wajib Pajak pada KPP Pratama Bandung Karees.

\subsection{Saran}

Setelah peneliti memberikan kesimpulan dari hasil penelitian tentang Pengetahuan Peraturan Perpajakan dan Kualitas Pelayanan terhadap Kepatuhan Wajib Pajak pada Kantor Pelayanan Pajak (KPP) Pratama Bandung Karees, maka peneliti akan memberikan beberapa saran sebagai berikut:

\subsubsection{Aspek Teoritis}

\section{Saran Bagi Akademisi}

Penelitian ini dapat digunakan untuk memperkaya wawasan para akademisi yang akan melakukan penelitian selanjutnya dengan memberikan berbagai literatur dan sumber yang dibutuhkan dalam penelitian, sehingga penelitian selanjutnya akan jadi lebih berkembang.

\section{Saran Bagi Peneliti Selanjutnya}

a. Disarankan bagi peneliti selanjutnya untuk melakukan penelitian dengan menggunakan variabel lain seperti kesadaran membayar pajak, persepsi atas efektifitas sistem perpajakan, dan lain sebagainya.

b. peneliti selanjutnya disarankan untuk menggunakan objek penelitian dari KPP yang tingkatnya berbeda, seperti KPP madya atau KPP besar.

\subsubsection{Aspek Praktis}

\section{Bagi Aparat Pajak}

Berdasarkan dari hasil tanggapan Wajib Pajak tentang Kualitas Pelayanan, penulis menilai bahwa Kualitas Pelayanan masih rendah di KPP Pratama Bandung Karees. Oleh karena itu penulis memberikan saran kepada KPP Pratama Bandung Karees, yaitu sebaiknya KPP Pratama Bandung Karees:

a. Melengkapi data Wajib Pajak.

b. Wajib Pajak tidak dibiarkan menunggu terlalu lama dan memudahkan Wajib Pajak dalam memperoleh pelayanan.

c. Bersikap ramah dan sopan serta memberikan pelayanan secara tepat waktu.

d. Memberikan pelayanan yang sama kepada setiap Wajib Pajak dan memberikan penjelasan yang mudah dimengerti oleh Wajib Pajak. 
JAFTA — Vol. 1 Nomor 2, September (2019)

e. Wajib Pajak memanfaatkan media informasi pajak yang disediakan di KPP Pratama Bandung Karees.

\section{Bagi Wajib Pajak}

Berdasarkan dari hasil tanggapan Account Representative dan pemeriksa pajak mengenai kepatuhan Wajib Pajak, penulis menilai bahwa kepatuhan Wajib Pajak masih rendah di KPP Pratama Bandung Karees. Penulis memberikan saran kepada Wajib Pajak di KPP Pratama Bandung Karees:

a. Wajib pajak mengisi formulir pajak dengan lengkap dan jelas.

b. Menghitung jumlah pajak yang terutang dengan benar.

c. Membayar pajak yang terutang tepat pada waktunya.

d. Menyampaikan atau melaporkan Surat Pemberitahuan (SPT) tepat pada waktunya untuk meningkatkan kepatuhan Wajib Pajak di KPP Pratama Bandung Karees.

\section{DAFTAR PUSTAKA}

Andi, Sri Rizki Utami, Ayu Noorida Soerono (2012),Pengaruh Faktor-Faktor Eksternal terhadap Tingkat Kepatuhan Wajib pajak, Serang: Universitas Sultan Ageng Tirtayasa.

Drs. Saryadi, Yuli Anita Siregar, dan Sari Listyorini (2010), Pengaruh Pelayanan Fiskus dan Pengetahuan Perpajakan terhadap Kepatuhan Wajib Pajak, Semarang: Universitas Diponegoro

Ghozali, Imam. (2011). Aplikasi Analisis Multivariate Dengan Program SPSS 19. Semarang : Badan Penerbit Universitas Diponegoro.
Mardiasmo (2009), Perpajakan Edisi Revisi 2009, Jakarta, Andi.

My Tax Profesional Software, edisi 2011.

Narimawati, Umi., (2007). Riset Manajemen Sumber Daya Manusia Aplikasi Contoh dan Perhitungan, Jakarta: Agung Media.

Nur Hidayati, Supriyati (2008), Pengaruh Pengetahuan Pajak dan Persepsi Wajib Pajak terhadap Kepatuhan Wajib Pajak, Surabaya: STIE Perbanas.

Odd Helge Fjeldstad, Merima Ali, and Ingrid Hoem Sjursen (2013), Factors affecting tax compliance attitude in Africa: Evidence from Kenya, Tanzania, Uganda and South Africa, Bergen, Norway: Michelsen Institute.

Priyatno, Duwi. (2011), SPSS Analisis Statistik Data, Yogyakarta, MediaKom.

Rahayu, Siti Kurnia (2010), Perpajakan Indonesia Konsep \& Aspek Formal, Yogyakarta: Graha Ilmu.

Resmi, Siti (2008), Perpajakan: Teori dan Kasus, Jakarta: Salemba Empat.

Sanusi, Anwar. (2011). Metodologi Penelitian Bisnis. Jakarta: Salemba Empat.

Sedarmayanti., Syarifudin Hidayat. (2011), Metodologi penelitian, Bandung, CV Mandar Maju.

Sekaran, Uma. (2009). Metodoogi Penelitian untuk Bisnis. Jakarta: Salemba Empat.

Sugiyono. (2011). Metodologi Penelitian Kuantitatif, Kualitatif, dan Kombinasi (Mixed Methods). Bandung: Alfabeta.

Sunyoto, Danang (2009). Analisis Regresi dan Uji Hipotesis. Yogyakarta: Medpres.

Undang-Undang Nomor 28 Tahun 2007 Tentang Ketentuan Umum dan Tata Cara Perpajakan.

Undang-Undang Nomor 36 Tahun 2008 Tentang Pajak Penghasilan. 
JAFTA — Vol. 1 Nomor 2, September (2019)

Undang-Undang Nomor 17 Tahun 2000 Tentang Subjek Pajak.

Undang-Undang Nomor 16 Tahun 2000 Tentang

Pemeriksaan Pajak.

Zain, Mohammad. (2007), Manajemen Perpajakan, Jakarta, Salemba Empat.

Zulaikha, Harjanti Puspa Arum (2012), Pengaruh Kesadaran Wajib Pajak, Pelayanan Fiskus, dan Sanksi Pajak terhadap Kepatuhan Wajib Pajak Orang Pribadi yang Melakukan Kegiatan Usaha dan Pekerjaan Bebas, Semarang: Universitas Diponegoro.

$\underline{\text { Internet }}$

www.kompas.com (diakses pada 5 Mei 2013)

www.pajak.go.id (diakses pada 5 Mei 2013) 
JAFTA — Vol. 1 Nomor 2, September (2019) 